\title{
5-Hydroxymethylcytosine correlates with epigenetic regulatory mutations, but may not have prognostic value in predicting survival in normal karyotype acute myeloid leukemia
}

\author{
Jae-Sook Ahn'1,2, Hyeoung-Joon Kim¹,2, Yeo-Kyeoung Kim ${ }^{1,2}$, Seung-Shin Lee ${ }^{1}$, Seo- \\ Yeon Ahn ${ }^{1}$, Sung-Hoon Jung ${ }^{1}$, Deok-Hwan Yang ${ }^{1}$, Je-Jung Lee ${ }^{1}$, Hee Jeong Park ${ }^{2}$, \\ Seung Hyun Choi ${ }^{2}$, Chul Won Jung ${ }^{3}$, Jun-Ho Jang ${ }^{3}$, Hee Je Kim', Joon Ho Moon ${ }^{5}$, \\ Sang Kyun Sohn ${ }^{5}$, Jong-Ho Won ${ }^{6}$, Sung-Hyun Kim7, Szardenings Michael ${ }^{8}$, Mark D. \\ Minden ${ }^{9}$, Dennis Dong Hwan Kim \\ ${ }^{1}$ Hematology-Oncology, Chonnam National University Hwasun Hospital, Jeollanam-do, Republic of Korea \\ ${ }^{2}$ Genomic Research Center for Hematopoietic Diseases, Chonnam National University Hwasun Hospital, Jeollanam-do, \\ Republic of Korea \\ ${ }^{3}$ Division of Hematology-Oncology, Samsung Medical Center, Seoul, Republic of Korea \\ ${ }^{4}$ Department of Hematology, Cancer Research Institute, Seoul St. Mary's Hospital, College of Medicine, The Catholic University \\ of Korea, Seoul, Republic of Korea \\ ${ }^{5}$ Department of Hematology-Oncology, Kyungpook National University Hospital, Daegu, Republic of Korea \\ ${ }^{6}$ Department of Hematology-Oncology, Soon Chun Hyang University Hospital, Seoul, Republic of Korea \\ ${ }^{7}$ Department of Hematology-Oncology, Dong-A University College of Medicine, Busan, Republic of Korea \\ ${ }^{8}$ Fraunhofer Institute for Cell Therapy and Immunology, Leipzig, Germany \\ ${ }^{9}$ Department of Medical Oncology and Hematology, Princess Margaret Cancer Centre, University of Toronto, Toronto, Canada \\ Correspondence to: Hyeoung-Joon Kim, email: hjoonk@chonnam.ac.kr \\ Keywords: TET2, IDH1/2, 5hmC, normal karyotype, AML
}

Received: July 25, $2016 \quad$ Accepted: November 24, $2016 \quad$ Published: December 26, 2016

\section{ABSTRACT}

Stem cells display remarkably high levels of 5 -hydroxymethylcytosine $(5 \mathrm{hmC})$. Both TET2 and IDH1/2 mutations can impair the production of $5 \mathrm{hmC}$, thus decreasing $5 \mathrm{hmC}$ levels. TET2 or IDH1/2 mutations are commonly observed in acute myeloid leukemia (AML). However, the implications of $5 \mathrm{hmC}$ on survival in normal karyotype AML patients have not been fully evaluated. The $5 \mathrm{hmC}$ levels were analyzed in $\mathbf{3 7 5}$ patients using ELISA. The levels of $5 \mathrm{hmC}$ in DNA samples were converted to a log scale for the analysis and correlations with TET2 and/or IDH1/2 mutations were evaluated. The median $5 \mathrm{hmC}$ level was $0.065 \%$ (range $0.001-0.999$ ). Mutation rates were $13.1 \%$ for $T E T 2^{\text {mut }}, 6.7 \%$ for IDH1 ${ }^{\text {mut }}$, and $13.9 \%$ for IDH2 ${ }^{\text {mut }}$. The prevalence of TET2 and/or IDH1/ 2 was $33.1 \%(124 / 375)$. TET2 and IDH1/2 mutated patients had significantly lower levels of $\log (5 \mathrm{hmC})$ compared with patients without TET2 or IDH1/2 mutations $(p<0.001)$. With a median follow-up of 55.5 months (range, 0.7-179.8), there was no significant difference in overall survival, event-free survival, and relapse risk according to $T E T 2^{\text {mut }}$ or $I D H 1 / 2^{\text {mut }}$ (all, $p>0.05$ ). To identify its prognostic value, we sub-classified the levels of $5 \mathrm{hmC}$ into tertiles for $5 \mathrm{hmC}$ values. However, there was no significant association between the categories of $5 \mathrm{hmC}$ levels and survival or relapse risk (all $p>0.05$ ). Patients with TET2 or IDH1/2 mutations had lower levels of $5 \mathrm{hmC}$. The $5 \mathrm{hmC}$ levels may not be predictive of survival in patients with normal karyotype AML.

\section{INTRODUCTION}

DNA methylation regulates the expression of specific genes and therefore plays a critical role in development, contributing to normal cellular differentiation, genomic stability, X-chromosome inactivation, and genomic imprinting [1]. The balance between methylation and demethylation 
is controlled by several proteins and cofactors. This balance is frequently deregulated in cancer, leading to aberrant methylation patterns [2]. The regulation of DNA hydroxymethylation is mediated by several factors including proteins from the TET family, which is responsible for the formation of 5-hydroxymethylcytosine $(5 \mathrm{hmC})$ [3]. TET proteins require $\alpha$-ketoglutarate $(\alpha \mathrm{KG})$ as a co-substrate, which is produced by the family of isocitrate dehydrogenase $(I D H)$ proteins [4]. IDH proteins catalyze the oxidative decarboxylation of isocitrate to $\alpha \mathrm{KG}$, which is an intermediate step in the tricarboxylic acid cycle $[5,6]$.

Several genes that influence hydroxymethylation are mutated in cancer. For example, mutations that disrupt TET expression or activity can affect the normal level of $5 \mathrm{hmC}$. In addition, this level may be affected by changes in the expression of either genes coding for products that bind $5 \mathrm{hmC}$ or genes involved in demethylation [2].

Mutations that disrupt the functions of TET and $I D H 1 / 2$ genes cause changes in $5 \mathrm{hmC}$ levels of hematopoietic stem cells and have been shown to participate in the pathogenesis of hematopoietic malignancies [4, 7-9]. TET2 mutations occur in $7-23 \%$ of patients with acute myeloid leukemia (AML) [4, 10-13] . The frequencies of $I D H 1$ and $I D H 2$ mutations in patients with AML are 5.5-14\% and 8.7-19\%, respectively [14]. A meta-analysis reported that TET2 mutations negatively affect the prognosis of patients with normal karyotype (NK)-AML, while the prognostic implications of $I D H 1 / 2$ mutations in patients with NK-AML are unclear $[14,15]$. However, the prognostic significance of TET2 mutations in NK-AML is controversial [10, 13].

$5 \mathrm{hmC}$ may function as an intermediate in demethylation and is known to be a transcriptional activator [16]. However, the prognostic implications of $5 \mathrm{hmC}$ have not been comprehensively evaluated in patients with NK-AML, especially in those affected by mutations. Additionally, the clinical significance of $5 \mathrm{hmC}$ levels has not been fully evaluated in patients with NK-AML. Herein, we evaluated the correlation of $5 \mathrm{hmC}$ levels with mutant alleles, as well as the significance of $5 \mathrm{hmC}$ levels in the context of survival and relapse risk.

\section{RESULTS}

\section{5hmC level and somatic mutations}

The characteristics of these 375 patients are summarized in Table 1. The median $5 \mathrm{hmC}$ level was $0.065 \%$ (0.001-1.000). The levels of $5 \mathrm{hmC}$ deviated from the standard normal distribution and were therefore reanalyzed using a log scale.

The prevalence rates of mutations were $13.1 \%$ $(\mathrm{n}=49 / 375)$ for $T E T 2^{m u t}, 6.7 \%(\mathrm{n}=25 / 375)$ for $I D H 1^{m u t}$, and
$13.9 \%(52 / 375)$ for $I D H 2^{m u t}$. The mutation rate of TET2 or $I D H 1 / 2$ was $33.1 \%(n=124 / 375)$. Of the 375 patients analyzed, 59 different TET2 mutations were detected in 49 of these patients (13.1\%). Of these 59 TET2 mutations, 13 were nonsense, 28 were frameshift, and 18 were missense. TET2 gene double mutations were detected in 12 patients, while a homozygous TET2 mutation was observed in 14 patients. The position and type of TET2 mutations are described in Supplementary Figure 1. Twenty-five patients had an IDH1 mutation in codon 132, whereas 52 patients had an IDH2 mutation in codon $140(\mathrm{n}=45)$ or codon 172 $(\mathrm{n}=7)$.

The prevalence rates of other mutations were: FLT3ITD $^{\text {pos }}, 27.7 \%$ (104/375); NPM1 ${ }^{\text {mut }}, 44.5 \%$ (167/375); $D N M T 3 A^{\text {mut }}, 33.2 \%$ (124/374); NRA $S^{\text {mut }}, 11.2 \%$ (42/374); $C E B P A^{\text {mut }}$ (double), $12.8 \%$ (48/374); WT1 $1^{\text {mut }}, 9.1 \%$ (34/374); ASXL1 ${ }^{\mathrm{mut}}, 7.0 \%$ (26/369); FAT1 ${ }^{\mathrm{mut}}, 6.1 \%$ (23/374); DNAH11 ${ }^{\mathrm{mut}}, 4.3 \%$ (16/374); and GATA2 $2^{\mathrm{mut}}, 3.3 \%$ (12/363) (Table 1).

\section{$5 \mathrm{hmC}$ level inversely correlates with adverse clinical factors of treatment outcomes}

We analyzed the levels of $5 \mathrm{hmC}$ according to the clinical factors with adverse outcomes. Older age $(\mathrm{r}=$ $-0.151, p=0.027)$, high WBC count $(r=-0.195, p<0.001)$, high blast percentage in bone marrow $(r=-0.129$, $p=0.013)$, and high peripheral blast counts $(r=-0.183$, $p<0.001)$ were inversely correlated with a low $5 \mathrm{hmC}$ level on a $\log$ scale. The $\log (5 \mathrm{hmC})$ levels were not significantly correlated with gender $(\mathrm{p}=0.372)$ or $\mathrm{CR}$ achievement $(p=0.807)$. In the sub-classification of the $5 \mathrm{hmC}$ values into tertiles, the high $5 \mathrm{hmC}$ group was younger and had a lower WBC count than the low or intermediate group. The low $5 \mathrm{hmC}$ group had a higher bone marrow blast percent than the intermediate or high $5 \mathrm{hmC}$ group (Table 1). $N P M 1^{\text {mut }}, D N M T 3 A^{\text {mut }}$ and $A S X L 1^{\text {mut }}$ were observed more frequently in the low $5 \mathrm{hmC}$ groups, while $C E B P A^{\mathrm{dm}}$ was more frequent in the high 5 hmC group $(p<0.05)$ (Table 1$)$.

\section{$5 \mathrm{hmC}$ levels correlate with the presence of $T E T 2$ or IDH1/2 mutations}

We examined whether $5 \mathrm{hmC}$ values correlated with TET2 or IDH1/2mutation status. The $\log (5 \mathrm{hmC})$ levels were lower in TET2 or IDH1/2 mutated groups than in the wild type (Figure 1). The levels of $5 \mathrm{hmC}$ were as follows: TET2 ${ }^{\text {mut }}$ (median 0.051\%, range 0.002-0.120), TET2 ${ }^{\text {wild }}$ (median $0.070 \%$, range $0.001-0.999), I D H 1^{\text {mut }}$ (median $0.044 \%$, range $0.004-0.073$ ), IDH1 ${ }^{\text {wild }}$ (median $0.069 \%$, range $0.001-$ 0.999 ), $I D H 2^{\text {mut }}$ (median $0.050 \%$, range $0.001-0.118$ ), $I D H 2^{\text {wild }}$ (median 0.069, range 0.001-0.999), any mutation of TET2 or $I D H 1 / 2$ (median $0.048 \%$, range $0.001-0.120$ ), and $T E T 2^{\text {wild }}$ and $I D H 1 / 2^{\text {wild }}$ (median 0.086, range 0.001-0.999). TET2 $2^{\text {mut }}$, IDH $1^{\text {mut }}$, and TET2 or IDH1/2 mutated patients had significantly lower levels of $\log (5 \mathrm{hmC})$ than patients without 
Table 1: Patient characteristics according to the 5-hydroxymethylcytosine levels

\begin{tabular}{|c|c|c|c|c|c|}
\hline & Total & $\begin{array}{c}\text { Low } \\
\text { 5hmC group }\end{array}$ & $\begin{array}{l}\text { Intermediate } \\
5 \mathrm{hmC} \text { group }\end{array}$ & $\begin{array}{c}\text { High } \\
\text { 5hmC group }\end{array}$ & $P$-value ${ }^{1)}$ \\
\hline No. of patients $(\%)$ & 375 & $124(33.1)$ & $125(33.3)$ & $126(33.6)$ & NA \\
\hline $5 \mathrm{hmC}, \%$ (range) & $0.065(0.001-1.000)$ & $0.030(0.001-0.051)$ & $\begin{array}{c}0.065(0.051- \\
0.089)\end{array}$ & $\begin{array}{c}0.093(-3.05- \\
1.000)\end{array}$ & NA \\
\hline $\begin{array}{l}\text { Age in years, median } \\
\text { (range) }\end{array}$ & $52(15-83)$ & $55(20-83)$ & $54(15-83)$ & $47(15-84)$ & $<0.001^{2), 3)}$ \\
\hline Gender, male (\%) & $190(50.7)$ & $62(50.0)$ & $62(49.6)$ & $66(51.7)$ & 0.859 \\
\hline $\begin{array}{l}\text { WBC, x } 10^{9} / \mathrm{L} \text {, median } \\
\text { (range) }\end{array}$ & $27.0(0.3-397.2)$ & $42.7(0.7-333.2)$ & $\begin{array}{l}27.3(0.5- \\
397.2)\end{array}$ & $15.4(0.3-292.5)$ & $<0.001^{2), 3)}$ \\
\hline Marrow blast, \% (range) & $72(1-100)$ & $79(2-100)$ & $70(1-100)$ & $70(10-100)$ & $<0.001^{2), 4)}$ \\
\hline Achievement of CR, (\%) & $309 / 375(82.4)$ & $106(85.5)$ & $98(78.4)$ & $105(83.3)$ & 0.322 \\
\hline Received allogeneic SCT & $106 / 375(28.3)$ & $31 / 124(25.0)$ & $32 / 125(25.6)$ & $43 / 126(34.1)$ & 0.184 \\
\hline $\begin{array}{l}\text { 5-year relapse risk, \% } \\
(95 \% \mathrm{CI})\end{array}$ & $44.7 \%(38.8-50.5)$ & $39.7(30.0-49.2)$ & $\begin{array}{l}43.5(33.0- \\
53.4)\end{array}$ & $48.9(39.9-58.2)$ & 0.593 \\
\hline $\begin{array}{l}5 \text {-year EFS rate, \% } \\
(95 \% \mathrm{CI})\end{array}$ & $33.0 \%(27.9-38.1)$ & $34.1(25.1-43.1)$ & $\begin{array}{c}31.9(23.3- \\
40.5)\end{array}$ & $30.4(22.2-38.6)$ & 0.835 \\
\hline 5 -year OS rate, $\%(95 \% \mathrm{CI})$ & $37.4 \%(32.1-42.7)$ & $40.3(31.1-49.5)$ & $\begin{array}{c}38.0(29.2- \\
46.8)\end{array}$ & $31.4(23.0-39.8)$ & 0.760 \\
\hline IDHI/2 mutated, $\%$ & $77 / 375(20.5)$ & $42(33.9)$ & $33(26.4)$ & $2(1.6)$ & $<0.001$ \\
\hline TET2 mutated, $\%$ & $49 / 375(13.1)$ & $23(18.5)$ & $23(18.4)$ & $3(2.4)$ & $<0.001$ \\
\hline FLT3-ITD mutated, $\%$ & $104 / 375(27.7)$ & $35(28.3)$ & $35(28.0)$ & $34(27.0)$ & 0.973 \\
\hline NPM1 mutated, $\%$ & $167 / 375(44.5)$ & $62(50.0)$ & $60(48.0)$ & $45(35.7)$ & 0.048 \\
\hline$C E B P A$ double mutated, $\%$ & $48 / 374(12.8)$ & $11(8.9)$ & $13(10.4)$ & $24 / 125(19.2)$ & 0.031 \\
\hline DNMT3A mutated, $\%$ & $124 / 374(33.2)$ & $48(38.7)$ & $46(36.8)$ & $30 / 125(24.0)$ & 0.027 \\
\hline WT1 mutated, $\%$ & $34 / 374(9.1)$ & $9(7.3)$ & $8(6.4)$ & $17 / 125(13.6)$ & 0.097 \\
\hline$N R A S$ mutated, \% & $42 / 374(11.2)$ & $11(8.9)$ & $16(12.8)$ & $15 / 125(12.0)$ & 0.584 \\
\hline FAT1 mutated, $\%$ & $23 / 374(6.1)$ & $5(4.0)$ & $7(5.6)$ & $11 / 125(8.8)$ & 0.279 \\
\hline$A S X L 1$ mutated, $\%$ & $26 / 369(7.0)$ & $15(12.4)$ & $5 / 124(4.0)$ & $6 / 124(4.8)$ & 0.019 \\
\hline DNAH11 mutated, $\%$ & $16 / 374(4.3)$ & $3(2.4)$ & $6(4.8)$ & $7 / 125(5.6)$ & 0.435 \\
\hline GATA2 mutated, $\%$ & $12 / 363(3.3)$ & 2/119 (1.7) & $3 / 121(2.5)$ & $7 / 123(5.7)$ & 0.180 \\
\hline
\end{tabular}

1) The $p$-values refer to comparisons among three groups according to levels of $5 \mathrm{hmC}$.

2) The $p$-values refer to comparisons between groups with low vs. high $5 \mathrm{hmC}$ levels.

3) The $p$-values refer to comparisons between groups with intermediate vs. high $5 \mathrm{hmC}$ levels.

4) The $p$-values refer to comparisons between groups with low vs. intermediate $5 \mathrm{hmC}$ levels.

Abbreviations: 5hmC, 5-hydroxymethylcytosine; WBC, white blood cells; CR, complete remission; SCT, stem cell transplantation; EFS, event-free survival; CI, confidence interval; OS, overall survival

mutations (all $p<0.001$ ) (Figure 1, Table 2). Older age, a high WBC count and a higher blast percentage in bone marrow were observed in the TET2 $2^{\text {mut }}$ or $I D H 1 / 2^{\text {mut }}$ group and each mutated group. Low rate of undergoing allogeneic stem cell transplantation (SCT) at the first complete remission (CR1) was observed in the $T E T 2^{\text {mut }}$ or $I D H 1 / 2^{\text {mut }}$ group and $T E T 2^{\text {mut }}$ group (Table 2).

\section{$5 \mathrm{hmC}$ levels are not prognostic with respect to the risk of relapse, EFS, or OS}

Of 375 patients receiving induction chemotherapy, $309(82.4 \%)$ achieved complete remission (CR). Of the 309 patients who achieved CR, 106 patients received allogeneic SCT as consolidation therapy. At a median 
Table 2: Patient characteristics and levels of 5-hydroxymethylcytosine according to TET2/IDH mutation status

\begin{tabular}{|c|c|c|c|c|c|c|c|c|c|c|}
\hline & Total & $\begin{array}{c}\boldsymbol{T E} \boldsymbol{T} 2^{\text {wild }} \text { and } \\
I D H 1 / 2 \text { wild }\end{array}$ & $\begin{array}{l}T E T 2^{\text {mut }} \text { or } \\
I D H 1 / 2^{\text {mut }}\end{array}$ & $\begin{array}{c}P_{-} \\
\text {value }^{1)}\end{array}$ & $T E T 2^{\mathrm{mut}}$ & $T E T 2^{\text {wild }}$ & $\begin{array}{c}P \text { - } \\
\text { value }^{2)}\end{array}$ & $I D H 1 / 2^{\mathrm{mut}}$ & $I D H 1 / 2$ wild & $\begin{array}{c}P \text { - } \\
\text { value }^{3)}\end{array}$ \\
\hline $\begin{array}{l}\text { No. of patients } \\
(\%)\end{array}$ & 375 & $\begin{array}{c}251 \\
(66.9)\end{array}$ & $\begin{array}{c}124 \\
(33.1)\end{array}$ & NA & $\begin{array}{c}49 \\
(13.1)\end{array}$ & $\begin{array}{c}326 \\
(86.9)\end{array}$ & NA & $\begin{array}{c}77 \\
(20.5)\end{array}$ & $\begin{array}{c}298 \\
(79.5)\end{array}$ & NA \\
\hline $\begin{array}{l}\text { Age, years, } \\
\text { median (range) }\end{array}$ & $\begin{array}{c}52 \\
(15-83)\end{array}$ & $50(15-84)$ & $61(16-83)$ & $<0.001$ & $\begin{array}{c}63 \\
(16-83)\end{array}$ & $\begin{array}{c}50 \\
(15-84)\end{array}$ & $<0.001$ & $\begin{array}{c}54 \\
(16-75)\end{array}$ & $\begin{array}{c}51 \\
(15-84)\end{array}$ & $<0.001$ \\
\hline Gender, male & $\begin{array}{c}190 \\
(50.7)\end{array}$ & $\begin{array}{c}125 \\
(50.0)\end{array}$ & $65(52.4)$ & 0.562 & $\begin{array}{c}23 \\
(46.9)\end{array}$ & $\begin{array}{c}167 \\
(51.2)\end{array}$ & 0.562 & $\begin{array}{c}42 \\
(54.5)\end{array}$ & $\begin{array}{c}148 \\
(49.8)\end{array}$ & 0.461 \\
\hline $\begin{array}{l}\text { WBC, x } 10^{9} / \mathrm{L}, \\
\text { median (range) }\end{array}$ & $\begin{array}{c}27.0 \\
(0.3-397.2)\end{array}$ & $\begin{array}{c}24.9 \\
(0.3-397.2)\end{array}$ & $\begin{array}{c}36.7(0.5- \\
333.2)\end{array}$ & $<0.001$ & $\begin{array}{c}41.7 \\
(0.9-282.0)\end{array}$ & $\begin{array}{c}25.1 \\
(0.3-397.2)\end{array}$ & $<0.001$ & $\begin{array}{c}25.2 \\
(0.5-333.2)\end{array}$ & $\begin{array}{c}27.3 \\
(0.3-397.2)\end{array}$ & $<0.001$ \\
\hline $\begin{array}{l}\text { Marrow blast, } \\
\% \text { (range) }\end{array}$ & $\begin{array}{c}72 \\
(1-100)\end{array}$ & $70(1-100)$ & $79(2-100)$ & $<0.001$ & $\begin{array}{c}75 \\
(3-100)\end{array}$ & $\begin{array}{c}72 \\
(1-100)\end{array}$ & $<0.001$ & $\begin{array}{c}80 \\
(2-100)\end{array}$ & $\begin{array}{c}69 \\
(1-100)\end{array}$ & $<0.001$ \\
\hline $\begin{array}{l}5 \mathrm{hmC}, \% \\
\text { (range) }\end{array}$ & $\begin{array}{c}0.065 \\
(0.001-0.99)\end{array}$ & $\begin{array}{c}0.086(0.001- \\
1.000)\end{array}$ & $\begin{array}{c}0.048 \\
(0.001-0.120)\end{array}$ & $<0.001$ & $\begin{array}{c}0.051 \\
(0.002- \\
0.120)\end{array}$ & $\begin{array}{c}0.070 \\
(0.001-0.999)\end{array}$ & $<0.001$ & $\begin{array}{c}0.047 \\
(0.001-0.094)\end{array}$ & $\begin{array}{c}0.074 \\
(0.001-1.00)\end{array}$ & $<0.001$ \\
\hline $\begin{array}{l}\mathrm{CR} \\
\text { achievement, } \\
(\%)\end{array}$ & $\begin{array}{c}309 / 375 \\
(82.4)\end{array}$ & $\begin{array}{c}212 \\
(84.8)\end{array}$ & $97(78.2)$ & 0.136 & $38(77.6)$ & $\begin{array}{c}271 \\
(83.1)\end{array}$ & 0.339 & $\begin{array}{c}60 \\
(77.9)\end{array}$ & $\begin{array}{c}249 \\
(83.6)\end{array}$ & 0.247 \\
\hline $\begin{array}{l}\text { Received } \\
\text { allogeneic SCT } \\
\text { in CR1 }\end{array}$ & $\begin{array}{c}106 / 309 \\
(28.3)\end{array}$ & $81 / 212(38.2)$ & $25 / 97(25.8)$ & 0.033 & $\begin{array}{c}7 / 38 \\
(18.4)\end{array}$ & $99 / 271(36.5)$ & 0.028 & $\begin{array}{l}20 / 60 \\
(33.3)\end{array}$ & $\begin{array}{c}86 / 249 \\
(35.0)\end{array}$ & 0.860 \\
\hline $\begin{array}{l}\text { 5-year relapse } \\
\text { risk, \% }(95 \% \\
\text { CI) }\end{array}$ & $\begin{array}{c}44.7 \\
(38.8-50.5)\end{array}$ & $\begin{array}{c}43.2 \\
(36.1-50.0)\end{array}$ & $\begin{array}{c}48.3(37.1- \\
58.6)\end{array}$ & 0.484 & $\begin{array}{c}49.3 \\
(30.9-65.4)\end{array}$ & $\begin{array}{c}44.1 \\
(37.8-50.2)\end{array}$ & 1.00 & $\begin{array}{c}46.2 \\
(32.5-58.9)\end{array}$ & $\begin{array}{c}44.2 \\
(37.6-50.6)\end{array}$ & 0.708 \\
\hline $\begin{array}{l}\text { 5-year EFS, \% } \\
(95 \% \mathrm{CI})\end{array}$ & $\begin{array}{c}33.0 \\
(27.9-38.1)\end{array}$ & $\begin{array}{c}34.8 \\
(28.5-41.1)\end{array}$ & $\begin{array}{c}29.2(20.4- \\
38.0)\end{array}$ & 0.260 & $\begin{array}{c}26.3 \\
(13.0-39.6)\end{array}$ & $\begin{array}{c}34.0 \\
(28.5-39.5)\end{array}$ & 0.334 & $\begin{array}{c}30.7 \\
(26.0-53.0)\end{array}$ & $\begin{array}{c}33.6 \\
(27.9-39.3)\end{array}$ & 0.450 \\
\hline $\begin{array}{l}5 \text {-year OS, \% } \\
(95 \% \mathrm{CI})\end{array}$ & $\begin{array}{c}37.4 \\
(32.1-42.7)\end{array}$ & $\begin{array}{c}39.0 \\
(32.5-45.5)\end{array}$ & $\begin{array}{c}34.1(25.1- \\
43.1)\end{array}$ & 0.303 & $\begin{array}{c}34.6 \\
(20.1-49.1)\end{array}$ & $\begin{array}{c}37.9 \\
(32.2-43.6)\end{array}$ & 0.502 & $\begin{array}{c}33.3(21.9- \\
44.7)\end{array}$ & $\begin{array}{c}38.5 \\
(32.6-44.4)\end{array}$ & 0.358 \\
\hline
\end{tabular}

1) The $p$-values refer to comparisons between groups with $T E T 2^{\text {wild }}$ and $I D H 1 / 2^{\text {wild }}$ vs. $T E T 2^{\text {mut }}$ or $I D H 1 / 2^{\text {mut }}$.

2) The $p$-values refer to comparisons between groups with $T E T 2^{\text {wild }}$ vs. $T E T 2^{\text {mut }}$.

3) The $p$-values refer to comparisons between groups with $I D H 1 / 2^{\text {wild }}$ vs. $I D H 1 / 2^{\text {mut }}$.

Abbreviations: 5hmC, 5-hydroxymethylcytosine; CR1, first complete remission; SCT, stem cell transplantation; RI, relapse incidence; CI, confidence interval; EFS, event-free survival; OS, overall survival; RI, relapse incidence; WBC, white blood cells

follow-up of 55.0 (range 0.9-179.8) months among survivors, 66 patients $(17.6 \%)$ failed to achieve CR, 129 patients (34.4\%) relapsed after CR was achieved, and 158 patients $(42.1 \%)$ died either from relapse $(n=109,39.1 \%)$ or from other causes $(n=49,13.1 \%)$. The relapse risk at 5 years was $44.7 \%$ (95\% CI 38.8-50.5\%). The event-free survival (EFS) and overall survival (OS) rates at 5 years were $33.0 \%$ (95\% CI 27.9-38.1\%) and 37.4\% (95\% CI $32.1-42.7 \%$ ), respectively.

At low, intermediate, and high levels of $5 \mathrm{hmC}$, the CR rates were $85.5 \%, 78.4 \%$, and $83.3 \%$, respectively $(p=0.322)$. The relapse risk, EFS, and OS did not differ
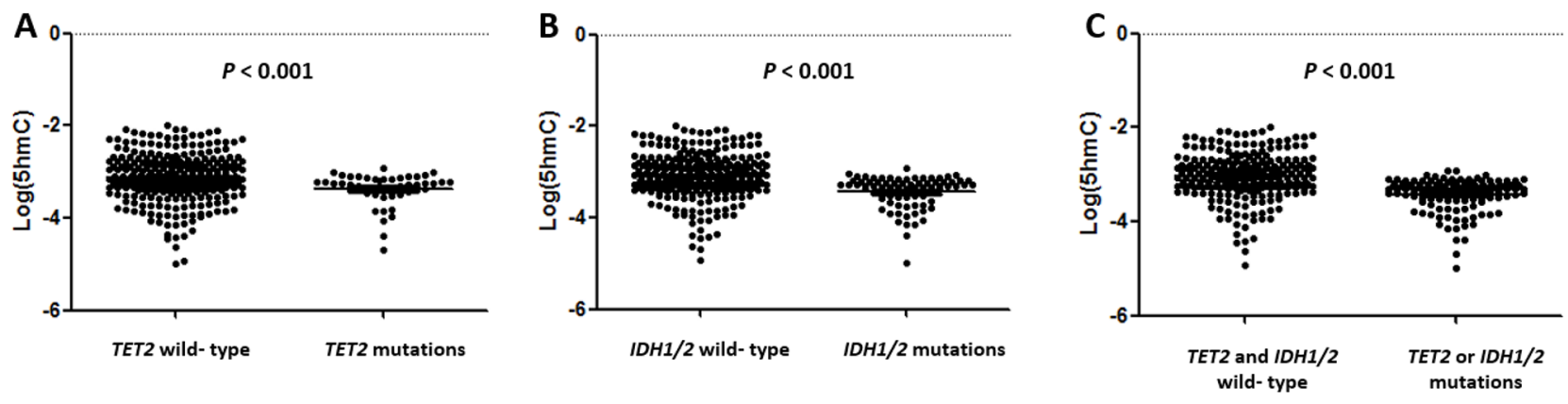

Figure 1: 5-Hydroxymethycytosine (5hmC) levels are decreased in patients with $T E T 2$ and $I D H$ mutations. Patients with TET2 A. IDH1/2 B. and TET2 or IDH1/2 C. mutations had significantly lower $5 \mathrm{hmC}$ levels than those with the TET2 wild type, IDH1/2 wild type, or both wild types (all $P<0.001$ ). 
significantly among patients in the different categories. Specifically, for the groups with low, intermediate, and high levels of $5 \mathrm{hmC}$, the relapse risk rates at 5 years were $39.7 \%, 43.5 \%$, and $48.9 \%(\mathrm{p}=0.593)$, the EFS rates at 5 years were $34.1 \%, 31.9 \%$, and $30.4 \%(\mathrm{p}=0.835)$, and the OS rates at 5 years were $40.3 \%, 38.0 \%$, and $31.4 \%$, respectively $(\mathrm{p}=0.760)$ (Figure 2$)$. There were no clinically significant differences in relapse risk, OS, and EFS according to the levels of $5 \mathrm{hmC}$ (all $p>0.05$ ).

Univariate analysis showed that $N P M 1^{\mathrm{mut}}$ $(p=0.006), \quad C E B P A^{\mathrm{dm}} \quad(p=0.002), \quad$ and receiving allogeneic SCT $(p=0.003)$ were associated with longer OS, while age ( $\geq 65$ years) $(p=0.020), D N M T 3 A^{\text {mut }}$ $(p=0.011)$, and FLT3-ITD ${ }^{\text {pos }}(p=0.001)$ were associated with worse OS. Furthermore, age ( $\geq 65$ years) $(p=0.002)$, WBC count $(p=0.034)$, peripheral blast count ( $p=0.045), F L T 3-$ ITD $^{\text {pos }}(p=0.008)$, and $A S X L 1^{\text {mut }}$ $(p=0.002)$ were associated with worse outcomes for EFS, while $N P M 1^{\mathrm{mut}}(p=0.003), C E B P A^{\mathrm{dm}}(p=0.001)$, and receiving allogeneic SCT $(p=0.003)$ were associated with favorable outcomes for EFS. $C E B P A^{\mathrm{dm}}$ $(p=0.003)$ and receiving allogeneic SCT $(p<0.001)$ were associated with a lower relapse risk, while age ( $\geq 65$ years) $(p=0.003)$ and FLT3-ITD ${ }^{\text {pos }}(p<0.001)$ were associated with a higher relapse risk.

The results of multivariate analysis are shown in Table 3. The results of $N P M 1^{\mathrm{mut}}$ and receiving allogeneic SCT were favorable, while $F L T 3-$ ITD $^{\text {pos }}$ and DNMT3 $A^{\text {mut }}$ were poor risk factors for OS. The results of $N P M 1^{\mathrm{mut}}$, $C E B P A^{\mathrm{dm}}$, and receiving allogeneic $\mathrm{SCT}$ were favorable, while $F L T 3-$ ITD $^{\text {pos }}$ and $D N M T 3 A^{\text {mut }}$ were poor risk factors, for EFS. In addition, age ( $\geq 65$ years), FLT3-ITD ${ }^{\text {pos }}$, and $A S X L 1^{\text {mut }}$ were significantly associated with a higher relapse risk, while $N P M 1^{\mathrm{mut}}, C E B P A^{\mathrm{dm}}$, and receiving allogeneic SCT reduced the relapse risk. There were no clinically significant differences in OS, EFS, and relapse risk according to the levels of $5 \mathrm{hmC}$ in multivariate analysis (all $p>0.05$ ).
We sub-analyzed the significance of levels of $5 \mathrm{hmC}$ according to each clinically significant mutational status. The levels of $5 \mathrm{hmC}$ did not influence the survival or relapse risk in each mutational status, even including that of TET2 or IDH1/2 (Supplementary Figure 2 and Supplementary Table 3).

\section{DISCUSSION}

We examined the prognostic implications and clinical significance of changes to $5 \mathrm{hmC}$ levels as a result of TET2 or IDH1/2 mutations. The $\log (5 \mathrm{hmC})$ levels were found to be inversely correlated with age, white blood cell (WBC) count, and the percentage of blasts in bone marrow. Patients with TET2 or IDH1/2 mutations had significantly lower levels of $\log (5 \mathrm{hmC})$ than patients without any TET2 or IDH1/2 mutations. However, when we sub-categorized the levels of $5 \mathrm{hmC}$ into tertiles, we found that low, intermediate, or high levels did not influence the achievement of CR. Furthermore, relapse risk, EFS, and OS were not found to be significantly different among the patients of any sub-group.

TET2 and IDH1/2 genes are important for regulating DNA methylation. Disruptions to their normal functions (i.e. alterations to DNA methylation) have been observed in several cancers. For example, in another study, it was demonstrated that AML patients with TET2 or IDH 1/2 mutations displayed decreased levels of $5 \mathrm{hmC}$ [12, 17-19]. The altered patterns of covalent cytosine modifications point to the potential for novel diagnostic, prognostic, and therapeutic applications. The level of 2-hydroxyglutarate in leukemic cells of AML patients (at the time of diagnosis) is suggested as an excellent surrogate marker for IDH1/2 mutations [16]. TET2 haploinsufficiency may contribute to abnormal myeloid transformation [7]. TET2 mutation occurs early in leukemogenesis, suggesting its significance in the onset and progression of hematologic malignancies [20]. Given that the levels of $5 \mathrm{hmC}$ indicate
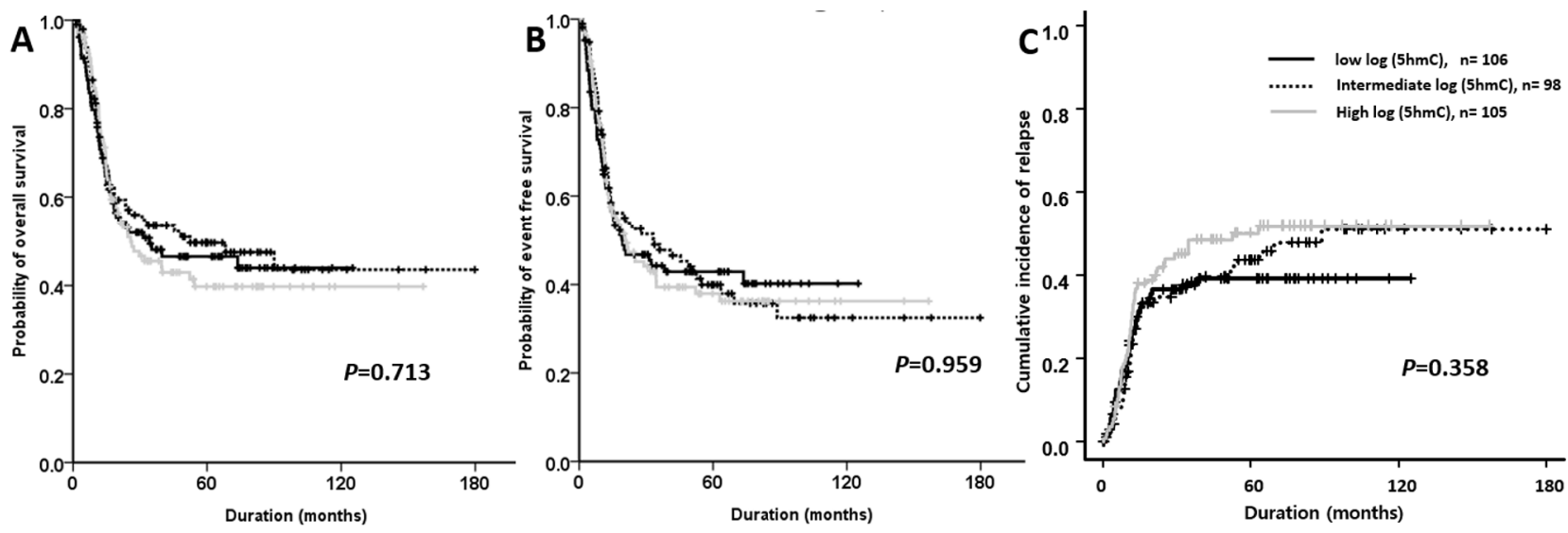

Figure 2: Outcomes of patients with normal karyotype acute myeloid leukemia according to the 5-hydroxymethylcytosine (5hmC) levels. Overall survival A. event-free survival B. and relapse incidence C. are shown. 
Table 3: Univariate and multivariate analyses of overall survival (OS), event-free survival (EFS), and relapse risk in patients with normal karyotype acute myeloid leukemia and risk factors including genetic and clinical factors at diagnosis

\begin{tabular}{|c|c|c|c|c|c|}
\hline \multirow[t]{2}{*}{ Parameter } & \multirow[t]{2}{*}{ Variable } & \multicolumn{2}{|c|}{ Univariate } & \multicolumn{2}{|c|}{ Multivariate } \\
\hline & & HR & $p$-value & HR & $p$-value \\
\hline \multirow[t]{12}{*}{ OS } & Age $\geq 65$ years & 1.480 & 0.020 & 1.240 & 0.339 \\
\hline & WBC count (cont) & 1.000 & 0.110 & 1.000 & 0.759 \\
\hline & Peripheral blast count (cont) & 1.000 & 0.129 & 1.000 & 0.605 \\
\hline & Allo SCT at CR1 & 0.593 & 0.003 & 0.552 & 0.002 \\
\hline & NPM1 mutation & 0.683 & 0.006 & 0.479 & $<0.001$ \\
\hline & $C E B P A$ double mutation & 0.482 & 0.002 & 0.632 & 0.096 \\
\hline & FLT3-ITD positive & 1.612 & 0.001 & 2.265 & $<0.001$ \\
\hline & $D N M T 3 A$ mutation & 1.424 & 0.011 & 1.750 & 0.003 \\
\hline & ASXL1 mutation & 1.430 & 0.137 & 0.994 & 0.986 \\
\hline & $5 \mathrm{hmC}(\mathrm{low})^{1)}$ & 1.000 & 0.869 & 0.983 & 0.924 \\
\hline & $(\text { intermediate) })^{2)}$ & 1.009 & 0.954 & 0.852 & 0.362 \\
\hline & $(\text { high })^{3)}$ & 1.075 & 0.869 & 1.152 & 0.406 \\
\hline \multirow[t]{12}{*}{ EFS } & Age $\geq 65$ years & 1.656 & 0.002 & 1.274 & 0.248 \\
\hline & WBC count (cont) & 1.000 & 0.034 & 1.000 & 0.876 \\
\hline & Peripheral blast count (cont) & 1.000 & 0.045 & 1.000 & 0.777 \\
\hline & Allo SCT at CR1 & 0.593 & 0.003 & 0.414 & $<0.001$ \\
\hline & NPM1 mutation & 0.679 & 0.003 & 0.459 & $<0.001$ \\
\hline & $C E B P A$ double mutation & 0.462 & 0.001 & 0.576 & 0.033 \\
\hline & FLT3-ITD positive & 1.454 & 0.008 & 2.087 & $<0.001$ \\
\hline & $D N M T 3 A$ mutation & 1.266 & 0.083 & 1.662 & 0.005 \\
\hline & ASXL1 mutation & 1.982 & 0.002 & 1.549 & 0.163 \\
\hline & $5 \mathrm{hmC}(\mathrm{low})^{1)}$ & 1.000 & 0.729 & 1.058 & 0.733 \\
\hline & $(\text { intermediate) })^{2)}$ & 1.022 & 0.888 & 0.942 & 0.715 \\
\hline & $(\text { high })^{3)}$ & 1.057 & 0.729 & 1.123 & 0.476 \\
\hline \multirow[t]{12}{*}{ Relapse risk } & Age $\geq 65$ years & 1.944 & 0.003 & 1.5800 & 0.044 \\
\hline & WBC count & 1.000 & 0.270 & 1.000 & 0.530 \\
\hline & Peripheral blast count & 1.000 & 0.290 & 1.000 & 0.300 \\
\hline & Allo SCT at CR1 & 0.346 & $<0.001$ & 0.347 & $<0.001$ \\
\hline & NPM1 mutation & 0.741 & 0.092 & 0.500 & $<0.001$ \\
\hline & $C E B P A$ double mutation & 0.372 & 0.003 & 0.373 & 0.005 \\
\hline & FLT3-ITD positive & 1.981 & $<0.001$ & 2.219 & $<0.001$ \\
\hline & $D N M T 3 A$ mutation & 1.184 & 0.380 & 1.461 & 0.088 \\
\hline & ASXL1 mutation & 1.882 & 0.062 & 1.774 & 0.009 \\
\hline & $5 \mathrm{hmC}(\mathrm{low})^{1)}$ & 0.797 & 0.250 & 0.803 & 0.171 \\
\hline & $(\text { intermediate) })^{2)}$ & 0.951 & 0.780 & 0.916 & 0.650 \\
\hline & $(\text { high })^{3)}$ & 1.312 & 0.140 & 1.377 & 0.121 \\
\hline
\end{tabular}

Abbreviations: WBC, white blood cells; 5hmC, 5-hydroxymethylcytosine; Allo SCT, allogeneic stem cell transplantation; CR1, first complete remission; HR, hazard ratio; cont, continuous variable

1) The HR and $p$-values refer to comparisons between groups with low $5 \mathrm{hmC}$ levels vs. intermediate and high levels.

2) The HR and $p$-values refer to comparisons between groups with intermediate $5 \mathrm{hmC}$ levels vs. low and high levels.

3) The HR and $p$-values refer to comparisons between groups with high $5 \mathrm{hmC}$ levels vs. low and intermediate levels. 
the presence of TET2 or IDH1/2 mutations, we speculate that $5 \mathrm{hmC}$ could also be a predictive marker for the prognosis and detection of TET2 or IDH1/2 mutations.

The significance of $5 \mathrm{hmC}$ levels in AML is unclear. Kroeze et al. previously attempted to demonstrate the effect of 5hmC levels on AML [19]. Specifically, they showed that the levels of $5 \mathrm{hmC}$ during $\mathrm{CR}$ were normalized to those levels seen in healthy bone marrow and peripheral blood. This indicated that aberrant levels of $5 \mathrm{hmC}$ at diagnosis were an intrinsic property of leukemic cells [19]. Interestingly, they also demonstrated that high levels of $5 \mathrm{hmC}$ were associated with a poor prognosis (as per a multivariate analysis), along with variable results of the effects of TET2 or IDH1/2 mutations on survival. Since the group with high levels of $5 \mathrm{hmC}$ was small $(8.2 \%, 17 / 206)$, the results cannot be generalized to all AML patients. In our cohort, there was no significant difference in survival according to the levels of $5 \mathrm{hmC}$. We tried to sub-classify the $5 \mathrm{hmC}$ value using $\mathrm{R}$ partitioning to find the valuable cut-off range but, we did not find a significant cut-off value for levels of $5 \mathrm{hmC}$ in OS, EFS, and relapse risk. Therefore, we sub-classified the patients into low, intermediate, and high level tertile groups of $5 \mathrm{hmC}$ to determine clinical significance. The difference between our findings and those of previous studies can likely be explained by the higher proportion of patients $>60$ years of age $(32.3 \%)$; furthermore, the effects of cytogenetic abnormalities on the levels of $5 \mathrm{hmC}$ were not considered in our study. The levels of $5 \mathrm{hmC}$ decline with aging, so the inclusion of older patients could influence the results of $5 \mathrm{hmC}$ [21]. We observed similar results in the NK-AML population with respect to the inverse correlation between $\log (5 \mathrm{hmC})$ levels and age. WBC count and the percentage of blasts in bone marrow were also negatively correlated with $\log (5 \mathrm{hmC})$ levels. In our previous study, TET2 mutations were associated with older age and a high WBC count. This suggests that patients with high WBC counts have more TET2 mutations, which might explain the correlation [13]. Our study shows that the $5 \mathrm{hmC}$ levels positively correlated with $C E B P A^{\mathrm{dm}}$, but negatively correlated with $N P M 1^{\text {mut }}, D N M T 3 A^{\text {mut }}$ and $A S X L 1^{\text {mut }}$. To our knowledge, no report has directly explained the relationship of $5 \mathrm{hmC}$ levels and $C E B P A^{\mathrm{dm}}, N P M 1^{\mathrm{mut}}, D N M T 3 A^{\mathrm{mut}}$, and $A S X L 1^{\mathrm{mut}}$. Previously, we showed that $T E T 2^{\text {mut }}$ is mutually exclusive with $C E B P A^{\mathrm{dm}}$, but has a positive correlation with $N P M 1^{\mathrm{mut}}$ [13]. DNMT3 $A^{\mathrm{mut}}$ and $C E B P A^{\mathrm{dm}}$ are also mutually exclusive, whereas $D N M T 3 A^{\text {mut }}$ was positively correlated with $N P M 1^{\text {mut }}$ [22]. We speculate that mutations of epigenetic modifying genes influence the associated mutational status of the $5 \mathrm{hmC}$ groups.

Our results have significant clinical relevance because the study population was restricted, exclusively, to patients with NK-AML. Furthermore, all patients received induction chemotherapy, while any untreated patients were excluded. However, this study had a methodological limitation given that Sanger's fluorescent dideoxynucleotide chain termination sequencing analysis has a detection sensitivity of approximately $10 \%$ of mutant alleles. Recently, a novel technology for next-generation sequencing was developed. This technology recognizes unique sequences, provides depth of coverage and accuracy of sequencing [23], and offers a powerful tool that may become integral to resolving correlation clonal dynamics with levels of $5 \mathrm{hmC}$. In this study, we did not demonstrate the prognostic significance of $5 \mathrm{hmC}$ levels. However, TET2 mutations have been shown to predict the response of patients with myelodysplastic syndrome to hypomethylating agents [24]. Hypomethylating agents are used in the standard treatment of elderly patients with AML who are not eligible for standard induction therapy $[25,26]$. The investigation of $5 \mathrm{hmC}$ levels in such a population could be a good prognostic marker for prediction of the response to hypomethylating agents and to tailor therapies and assess responses to anticancer drugs [12].

In summary, TET2 or IDH1/2 mutated patients had lower levels of $5 \mathrm{hmC}$. Apart from affecting the methylation status of DNA, other processes may be influenced by altered levels of $5 \mathrm{hmC}$ in patients with $\mathrm{NK}$ AML and TET2 ${ }^{\text {wild }}$ and $I D H 1 / 2^{\text {wild }}$. 5hmC may not have prognostic value for predicting survival or relapse risk in patients with NK-AML who have been treated with intensive induction therapy.

\section{PATIENTS AND METHODS}

\section{Patients and treatment}

This study included patients diagnosed with NKAML at seven participating institutions between October 1998 and September 2012. Out of 407 patients screened for this study, 375 DNA samples were available to evaluate the levels of $5 \mathrm{hmC}$ [13]. The median patient age was 52 (range 15-83) years and the subjects included 190 males (Supplementary Table 1). Most cases were AML not otherwise specified $(88.8 \%)$, with some therapy-relapsed AML (2.9\%) or AML with myelodysplasia-related changes $(8.3 \%)$. Patients had received induction chemotherapy using a standard protocol [a 3-day course of anthracycline with a simultaneous 7-day course of cytosine arabinoside (Ara-C) or $\mathrm{N}^{4}$-behenoyl-1-b-d-arabinofuranosylcytosine (BHAC)] [13]. Idarubicin was administered daily at a dose of $12 \mathrm{mg} / \mathrm{m}^{2}$ or daunorubicin was administered at a dose of $60 \mathrm{mg} / \mathrm{m}^{2}$ on three consecutive days. Ara-C was administered daily at a dose of $100 \mathrm{mg} / \mathrm{m}^{2}$ and BHAC at a dose of $300 \mathrm{mg} / \mathrm{m}^{2}$ on seven consecutive days. In all, 210 patients were treated with idarubicin + Ara-C, 71 patients were treated with idarubicin + BHAC, and 94 patients received daunorubicin + Ara-C induction chemotherapy. Of 375 patients, 260 (69.3\%) achieved complete remission (CR) after first induction chemotherapy. Seventy-Two patients received second induction chemotherapy (44 
patients with first induction regimen, 13 patients with mitoxantrone based induction and, 15 patients with fludarabine based induction) and 43 patients achieved CR after second induction chemotherapy. Six out of 17 patients achieved CR after third induction chemotherapy. Patients who achieved $\mathrm{CR}$ received consolidation chemotherapy with or without allogeneic SCT, depending on the availability of an HLA-matched donor (related or unrelated). Genetic factors such as FLT3-ITD or NPM1 mutation were not considered when deciding whether to perform allogeneic SCT for consolidative treatment. Written informed consent was obtained from all subjects for the genetic analysis of samples taken at the time of diagnosis. The study was approved by the Institutional Review Board of Chonnam National University Hwasun Hospital, South Korea.

\section{Gene mutation analyses}

Cryopreserved bone marrow or peripheral blood samples taken at diagnosis were archived. Genomic DNA was extracted using QIAamp DNA blood mini-kits (QIAGEN, Valencia, CA, USA), as per the manufacturer's protocol. Mutation analyses were performed using Sanger sequencing and polymerase chain reaction (PCR). TET2, FLT3-ITD, and NPM1 mutation testing was performed as described previously [27, 28]. TET2 missense mutations were included in the analysis only when they were located within one of two evolutionarily conserved domains (amino acids 1,104-1,478 or 1,845-2,002) and identical TET2 mutations in both alleles were defined as homozygous [29, 30]. The DNMT3A, WT1, NRAS, ASXL2, and $I D H 1 / 2$ mutation analysis was performed as reported previously [31, 32] [29-35]. The CEBPA, FAT1, DNAH11, and GATA2 were amplified by genomic PCR; overlapping PCR products covering the entire coding sequence were generated and sequenced using the PCR primers in Supplementary Table 2. Amplification featured initial denaturation at $95^{\circ} \mathrm{C}$ for $5 \mathrm{~min}$, followed by 40 cycles of $94^{\circ} \mathrm{C}$ for $30 \mathrm{~s}, 62^{\circ} \mathrm{C}$ for $30 \mathrm{~s}$, and $72^{\circ} \mathrm{C}$ for $1 \mathrm{~min}$, and a final 10 -min extension at $72^{\circ} \mathrm{C}$. The amplification products were sequenced on an ABI 3100 platform using a cycle sequencing kit (BigDye Terminator; Applied Biosystems, Foster City, CA, USA).

\section{Level of $5 \mathrm{hmC}$}

The 5hmC levels were measured in 375 DNA samples using Quest 5hmC ${ }^{\mathrm{TM}}$ DNA ELISA Kits (Zymo Research, Boston, MA, USA). DNA (100 ng) from each patient or control was used for quantification. Biochemical assays were performed according to the manufacturer's recommendations and samples were read in a spectrophotometer at $450 \mathrm{~nm}$. Absolute quantification was performed using the concentrations of positive control samples by the standard curve method. The amount of
$5 \mathrm{hmC}$ was calculated from 100-ng samples of singlestranded DNA and is reported as a percentage (\%).

\section{Response and survival endpoints}

The definition of CR followed reported criteria [36]. Relapse risk was defined as the time from achieving remission to the date of relapse in all patients who achieved $\mathrm{CR}$, considering the competing risk of death without relapse. Non-relapse mortality (NRM) was defined as death occurring in the absence of relapse. EFS was defined as the time from commencing induction chemotherapy to the date of death from any cause, relapse, or non-achievement of CR, whichever occurred first. OS was defined as the time from the start of induction chemotherapy to the date of last followup, or death from any cause. Patients undergoing allogeneic HSCT were not censored at the time of transplantation.

\section{Statistical analyses}

First, we tried to sub-classify the $5 \mathrm{hmC}$ value using $\mathrm{R}$ partitioning to find the valuable cut-off range. However, we could not find a significant cut-off value for $5 \mathrm{hmC}(p>0.05)$. Therefore, we simply sub-classified the $5 \mathrm{hmC}$ values into tertiles. Descriptive statistics are presented as frequencies (\%) and medians (with ranges) for categorical and continuous variables, respectively. The clinical characteristics and treatment outcomes of each mutation were compared with each other. The $\chi^{2}$ test was used to compare the differences in categorical data distributions, while the Wilcoxon rank-sum test was used to evaluate the differences between continuous variables. ANOVA was used to evaluate the differences between continuous variables and compare three groups for statistical significance. Pearson and Spearman correlation coefficients were used to calculate the correlations between two continuous variables. EFS and OS were calculated using the Kaplan-Meier method; the differences among groups were compared using the log-rank test and Cox's proportional hazard model for univariate and multivariate analyses, respectively. Age, WBC count, peripheral blast count, receiving allogeneic $\mathrm{SCT}$, frequencies of $N P M 1^{\mathrm{mut}}, C E B P A^{\mathrm{mut}}$ (double), FLT3-ITD ${ }^{\text {pos }}, D N M T 3 A^{\text {mut }}$, and $A S X L 1^{\text {mut }}$, as well as the $5 \mathrm{hmC}$ level were included in the final multivariate model. Covariates with parameters that were significant in univariate analyses were included in the multivariate analysis. We also included the $5 \mathrm{hmC}$ level in the multivariate analysis to identify its clinical significance. The incidences of relapse and NRM were calculated using a cumulative incidence method that considered competing risks. Gray's test and the Fine-Gray test were used for univariate and multivariate comparisons, respectively [37]. $P$-values $<0.05$ were considered to be significant. Hazard ratios (HRs) and 95\% confidence intervals (CIs) were estimated using a predetermined value for reference risk 
unity. All statistical analyses were performed using SPSS ver. 21.0 (SPSS, Chicago, IL, USA) and EZR software in ' $R$ ' language (available at http://www.jichi.ac.jp/saitamasct/SaitamaHP.files/statmedEN.html) [37].

\section{CONFLICTS OF INTEREST}

The authors declare no conflicts of interest.

\section{GRANT SUPPORT}

This study was supported by a grant from the National Project for Personalized Genomic Medicine at the Ministry for Health \& Welfare, Republic of Korea (A111218-11GM06). This research was supported by the Basic Science Research Program through the National Research Foundation of Korea (NRF) as funded by the Ministry of Science, ICT and Future Planning (NRF-2015R1A2A1A10054579). Furthermore, support was received from a research grant from the Research Institute of Medical Sciences at Chonnam National University (2015-CURIMS-DR004). The biospecimens and data used for this study were provided by the Biobank of Chonnam National University Hwasun Hospital, a member of the Korea Biobank Network.

\section{REFERENCES}

1. Esteller M. Epigenetics in cancer. The New England Journal of Medicine. 2008; 358: 1148-1159.

2. Kroeze LI, van der Reijden BA and Jansen JH. 5-Hydroxymethylcytosine: An epigenetic mark frequently deregulated in cancer. Biochimica et Biophysica Acta. 2015; 1855: 144-154.

3. Ito S, Shen L, Dai Q, Wu SC, Collins LB, Swenberg JA, He $\mathrm{C}$ and Zhang Y. Tet proteins can convert 5-methylcytosine to 5-formylcytosine and 5-carboxylcytosine. Science. 2011; 333: 1300-1303.

4. Figueroa ME, Abdel-Wahab O, Lu C, Ward PS, Patel J, Shih A, Li Y, Bhagwat N, Vasanthakumar A, Fernandez HF, Tallman MS, Sun Z, Wolniak K, et al. Leukemic IDH1 and IDH2 mutations result in a hypermethylation phenotype, disrupt TET2 function, and impair hematopoietic differentiation. Cancer Cell. 2010; 18: 553-567.

5. Chan SM and Majeti R. Role of DNMT3A, TET2, and IDH1/2 mutations in pre-leukemic stem cells in acute myeloid leukemia. International Journal of Hematology. 2013; 98: 648-657.

6. Conway O'Brien E, Prideaux S and Chevassut T. The epigenetic landscape of acute myeloid leukemia. Advances in Hematology. 2014; 2014: 103175.

7. Moran-Crusio K, Reavie L, Shih A, Abdel-Wahab O, Ndiaye-Lobry D, Lobry C, Figueroa ME, Vasanthakumar A, Patel J, Zhao X, Perna F, Pandey S, Madzo J, et al. Tet2 loss leads to increased hematopoietic stem cell self-renewal and myeloid transformation. Cancer Cell. 2011; 20: 11-24.
8. Li Z, Cai X, Cai CL, Wang J, Zhang W, Petersen BE, Yang $\mathrm{FC}$ and $\mathrm{Xu}$ M. Deletion of Tet2 in mice leads to dysregulated hematopoietic stem cells and subsequent development of myeloid malignancies. Blood. 2011; 118: 4509-4518.

9. Visconte V, Tiu RV and Rogers HJ. Pathogenesis of myelodysplastic syndromes: an overview of molecular and non-molecular aspects of the disease. Blood Research. 2014; 49: 216-227.

10. Metzeler KH, Maharry K, Radmacher MD, Mrozek K, Margeson D, Becker H, Curfman J, Holland KB, Schwind S, Whitman SP, Wu YZ, Blum W, Powell BL, et al. TET2 mutations improve the new European LeukemiaNet risk classification of acute myeloid leukemia: a Cancer and Leukemia Group B study. Journal of Clinical Oncology. 2011; 29: 1373-1381.

11. Gaidzik VI, Paschka P, Spath D, Habdank M, Kohne CH, Germing U, von Lilienfeld-Toal M, Held G, Horst HA, Haase D, Bentz M, Gotze K, Dohner H, et al. TET2 mutations in acute myeloid leukemia (AML): results from a comprehensive genetic and clinical analysis of the AML study group. Journal of Clinical Oncology. 2012; 30: 1350-1357.

12. Ko M, Huang Y, Jankowska AM, Pape UJ, Tahiliani M, Bandukwala HS, An J, Lamperti ED, Koh KP, Ganetzky R, Liu XS, Aravind L, Agarwal S, et al. Impaired hydroxylation of 5-methylcytosine in myeloid cancers with mutant TET2. Nature. 2010; 468: 839-843.

13. Ahn JS, Kim HJ, Kim YK, Jung SH, Yang DH, Lee JJ, Lee IK, Kim NY, Minden MD, Jung CW, Jang JH, Kim HJ, Moon JH, et al. Adverse prognostic effect of homozygous TET2 mutation on the relapse risk of acute myeloid leukemia in patients of normal karyotype. Haematologica. 2015; 100: e351-353.

14. Zhou KG, Jiang LJ, Shang Z, Wang J, Huang L and Zhou JF. Potential application of IDH1 and IDH2 mutations as prognostic indicators in non-promyelocytic acute myeloid leukemia: a meta-analysis. Leukemia \& Lymphoma. 2012; 53: $2423-2429$.

15. Liu WJ, Tan XH, Luo XP, Guo BP, Wei ZJ, Ke Q, He S and Cen $\mathrm{H}$. Prognostic significance of Tet methylcytosine dioxygenase 2 (TET2) gene mutations in adult patients with acute myeloid leukemia: a meta-analysis. Leukemia \& Lymphoma. 2014; 55: 2691-2698.

16. Madzo J, Vasanthakumar A and Godley LA. Perturbations of 5-hydroxymethylcytosine patterning in hematologic malignancies. Seminars in Hematology. 2013; 50: 61-69.

17. Konstandin N, Bultmann S, Szwagierczak A, Dufour A, Ksienzyk B, Schneider F, Herold T, Mulaw M, Kakadia PM, Schneider S, Spiekermann K, Leonhardt H and Bohlander SK. Genomic 5-hydroxymethylcytosine levels correlate with TET2 mutations and a distinct global gene expression pattern in secondary acute myeloid leukemia. Leukemia. 2011; 25: 1649-1652.

18. Pronier E, Almire C, Mokrani H, Vasanthakumar A, Simon A, da Costa Reis Monte Mor B, Masse A, Le Couedic JP, Pendino F, Carbonne B, Larghero J, Ravanat JL, Casadevall 
$\mathrm{N}$, et al. Inhibition of TET2-mediated conversion of 5-methylcytosine to 5-hydroxymethylcytosine disturbs erythroid and granulomonocytic differentiation of human hematopoietic progenitors. Blood. 2011; 118: 2551-2555.

19. Kroeze LI, Aslanyan MG, van Rooij A, KoorenhofScheele TN, Massop M, Carell T, Boezeman JB, Marie JP, Halkes CJ, de Witte T, Huls G, Suciu S, Wevers RA, et al. Characterization of acute myeloid leukemia based on levels of global hydroxymethylation. Blood. 2014; 124: 1110-1118.

20. Shlush LI, Zandi S, Mitchell A, Chen WC, Brandwein JM, Gupta V, Kennedy JA, Schimmer AD, Schuh AC, Yee KW, McLeod JL, Doedens M, Medeiros JJ, et al. Identification of pre-leukaemic haematopoietic stem cells in acute leukaemia. Nature. 2014; 506: 328-333.

21. Buscarlet M, Tessier A, Provost S and Busque L. Human blood cell level of 5-hydroxymethylcytosine $(5 \mathrm{hmC})$ declines steadily during aging and is multifactorial. Blood. 2015; 126: 1179-1181.

22. Ahn JS, Kim HJ, Kim YK, Lee SS, Jung SH, Yang DH, Lee JJ, Kim NY, Choi SH, Jung CW, Jang JH, Kim HJ, Moon JH, et al. DNMT3A R882 Mutation with FLT3-ITD Positivity is an extremely poor prognostic factor in patients with normal-karyotype acute myeloid leukemia after allogeneic hematopoietic cell transplantation. Biology of Blood and Marrow Transplantation. 2016; 22: 61-70.

23. Mori A, Deola S, Xumerle L, Mijatovic V, Malerba G and Monsurro V. Next generation sequencing: new tools in immunology and hematology. Blood Research. 2013; 48: 242-249.

24. Bejar R, Lord A, Stevenson K, Bar-Natan M, Perez-Ladaga A, Zaneveld J, Wang H, Caughey B, Stojanov P, Getz G, GarciaManero G, Kantarjian H, Chen R, et al. TET2 mutations predict response to hypomethylating agents in myelodysplastic syndrome patients. Blood. 2014; 124:2705-2712.

25. Kantarjian HM, Thomas XG, Dmoszynska A, Wierzbowska A, Mazur G, Mayer J, Gau JP, Chou WC, Buckstein R, Cermak J, Kuo CY, Oriol A, Ravandi F, et al. Multicenter, randomized, open-label, phase III trial of decitabine versus patient choice, with physician advice, of either supportive care or low-dose cytarabine for the treatment of older patients with newly diagnosed acute myeloid leukemia. Journal of Clinical Oncology. 2012; 30: 2670-2677.

26. Fenaux P, Mufti GJ, Hellstrom-Lindberg E, Santini V, Gattermann N, Germing U, Sanz G, List AF, Gore S, Seymour JF, Dombret H, Backstrom J, Zimmerman L, et al. Azacitidine prolongs overall survival compared with conventional care regimens in elderly patients with low bone marrow blast count acute myeloid leukemia. Journal of Clinical Oncology. 2010; 28: 562-569.

27. Kim YK, Kim HN, Lee SR, Ahn JS, Yang DH, Lee JJ, Lee IK, Shin MG and Kim HJ. Prognostic significance of nucleophosmin mutations and FLT3 internal tandem duplication in adult patients with cytogenetically normal acute myeloid leukemia. The Korean Journal of Hematology. 2010; 45: 36-45.
28. Chou WC, Chou SC, Liu CY, Chen CY, Hou HA, Kuo YY, Lee MC, Ko BS, Tang JL, Yao M, Tsay W, Wu SJ, Huang SY, et al. TET2 mutation is an unfavorable prognostic factor in acute myeloid leukemia patients with intermediate-risk cytogenetics. Blood. 2011; 118: 3803-3810.

29. Langemeijer SM, Kuiper RP, Berends M, Knops R, Aslanyan MG, Massop M, Stevens-Linders E, van Hoogen P, van Kessel AG, Raymakers RA, Kamping EJ, Verhoef GE, Verburgh E, et al. Acquired mutations in TET2 are common in myelodysplastic syndromes. Nature Genetics. 2009; 41: 838-842.

30. Weissmann S, Alpermann T, Grossmann V, Kowarsch A, Nadarajah N, Eder C, Dicker F, Fasan A, Haferlach C, Haferlach T, Kern W, Schnittger S and Kohlmann A. Landscape of TET2 mutations in acute myeloid leukemia. Leukemia. 2012; 26: 934-942.

31. Tiacci E, Spanhol-Rosseto A, Martelli MP, Pasqualucci L, Quentmeier H, Grossmann V, Drexler HG and Falini B. The NPM1 wild-type OCI-AML2 and the NPM1-mutated OCIAML3 cell lines carry DNMT3A mutations. Leukemia. 2012; 26: 554-557.

32. Thol F, Weissinger EM, Krauter J, Wagner K, Damm F, Wichmann M, Gohring G, Schumann C, Bug G, Ottmann O, Hofmann WK, Schlegelberger B, Ganser A, et al. IDH1 mutations in patients with myelodysplastic syndromes are associated with an unfavorable prognosis. Haematologica. 2010; 95: 1668-1674.

33. Ahmad F, D'Souza W, Mandava S and Das BR. Molecular analysis of WT1 and KIT mutations in patients from an Indian population with de novo acute myeloid leukemia: determination of incidence, distribution patterns, and report of a novel KIT mutation. Leukemia \& Lymphoma. 2011; 52: 865-876.

34. Gelsi-Boyer V, Trouplin V, Adelaide J, Aceto N, Remy V, Pinson S, Houdayer C, Arnoulet C, Sainty D, Bentires-Alj M, Olschwang S, Vey N, Mozziconacci Mj et al. Genome profiling of chronic myelomonocytic leukemia: frequent alterations of RAS and RUNX1 genes. BMC Cancer. 2008; 8: 299.

35. Gelsi-Boyer V, Trouplin V, Adelaide J, Bonansea J, Cervera N, Carbuccia N, Lagarde A, Prebet T, Nezri M, Sainty D, Olschwang S, Xerri L, Chaffanet Met al. Mutations of polycomb-associated gene ASXL1 in myelodysplastic syndromes and chronic myelomonocytic leukaemia. British Journal of Haematology. 2009; 145: 788-800.

36. Cheson BD, Bennett JM, Kopecky KJ, Buchner T, Willman CL, Estey EH, Schiffer CA, Doehner H, Tallman MS, Lister TA, Lo-Coco F, Willemze R, Biondi A, et al. Revised recommendations of the International Working Group for Diagnosis, Standardization of Response Criteria, Treatment Outcomes, and Reporting Standards for Therapeutic Trials in Acute Myeloid Leukemia. Journal of Clinical Oncology. 2003; 21: 4642-4649.

37. Kanda Y. Investigation of the freely available easy-touse software 'EZR' for medical statistics. Bone Marrow Transplantation. 2013; 48: 452-458. 